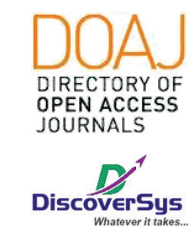

Published by DiscoverSys

\section{Teknik two step-cutaneous plasty shaft Penis dengan scrotal skin pada kasus parafinoma penis: laporan kasus}

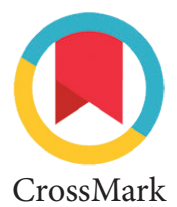

\author{
Putu Kurnia Darma Pratama, ${ }^{1 *}$ I Putu Gde Sanjaya²
}

\section{ABSTRACT}

Background: Penile injection of paraffin is one of procedure that people think can increase penile size. Nevertheless, many people do not know if paraffin injection causes significant adverse effects such as penile paraffinoma. A surgical procedure by wide excision of skin and subcutaneous tissue infiltrated by paraffin continued with appropriate phalloplasty could be done as definitive therapy with the good aesthetic and functional result. This case report aims to present penile parafinoma or sclerosing lipogranuloma due to subcutaneous penile injection of paraffin, its management and the result after surgical procedure.

Case: A 40-year-old man came to the Urology Polyclinic, Mangusada Badung Regional Hospital who presented with penile swelling and pain for 3 days. There was a history of subcutaneous penile injection of paraffin about one-year ago by non-medical personnel. On examination of genital organ, there was swelling on entire penile skin with tenderness and induration. A surgical procedure was performed using a two-step cutaneous plasty technique with scrotal flaps on the shaft of the penis. After two months, the surgical procedure gave an excellent penile aesthetic and functional result.

Conclusion: Penile parafinoma is a lipogranulomatous inflammatory reaction due to injection of paraffin substance, which cases are still found today, especially in Indonesia. Reconstructive surgery is the definitive therapy to overcome aesthetic or functional problems.

Keywords: Penile paraffinoma, penile paraffin injection, scrotal flap Cite This Article: Pratama, P.K.D., Sanjaya, I.P.G. 2019. Teknik two step-cutaneous plasty shaft Penis dengan scrotal skin pada kasus parafinoma penis: laporan kasus. Intisari Sains Medis 10(2): 442-447. D0I: 10.15562/ism.v10i2.408

\title{
ABSTRAK
}

Latar Belakang: Injeksi paraffin pada penis merupakan salah satu cara yang dipandang masyarakat dapat meningkatkan ukuran penis. Namun banyak yang tidak mengetahui bahwa injeksi parafin justru menimbulkan efek samping berupa parafinoma penis. Terapi definitif berupa eksisi luas pada kulit dan jaringan subkutan yang terinfiltrasi oleh parafin disertai dengan tindakan phalloplasty dapat dilakukan untuk mengatasi gangguan aestetik dan fungsional dari penis. Laporan kasus ini bertujuan untuk mempresentasikan kasus parafinoma penis atau sklerosing lipogranuloma akibat injeksi parafin pada penis secara subkutan, serta penatalaksanaannya.

Kasus: Seorang laki-laki berumur 40 tahun datang ke Poliklinik Urologi, Rumah Sakit Daerah Mangusada Badung dengan keluhan pembengkakan disertai nyeri pada penis sejak 3 hari. Terdapat riwayat injeksi parafin pada penis secara subkutan 1 tahun yang lalu oleh tenaga non-medis. Pada pemeriksaan organ genitalia didapatkan pembengkakan pada keseluruhan kulit penis disertai nyeri tekan dan indurasi. Tindakan operasi dilakukan menggunakan teknik two step cutaneous plasty dengan scrotal flap pada shaft penis. Didapatkan hasil yang baik secara aestetik dan fungsional pasca operasi.

Simpulan: Parafinoma penis merupakan reaksi inflamasi lipogranulomatosa akibat injeksi substansi paraffin, yang kasusnya masih sering ditemukan hingga saat ini, terutama di Indonesia. Tindakan operasi rekonstruksi merupakan terapi definitif untuk mengatasi permasalahan dari segi aestetik ataupun fungsional.
'Dokter Umum, Fakultas Kedokteran, Universitas Udayana, Bali, Indonesia

2Departemen Urologi, Rumah Sakit Umum Daerah Mangusada, Badung, Bali, Indonesia

\section{*Korespondensi:}

Putu Kurnia Darma Pratama; Dokter Umum, Fakultas Kedokteran, Universitas Udayana, Bali, Indonesia; kurniadarmapratama@gmail.com

Diterima: 02-02-2019

Disetujui: 24-05-2019

Diterbitkan: 01-08-2019
Kata kunci: Parafinoma penis, injeksi parafin penis, scrotal flap

Cite Pasal Ini: Pratama, P.K.D., Sanjaya, I.P.G. 2019. Teknik two step-cutaneous plasty shaft Penis dengan scrotal skin pada kasus parafinoma penis: Iaporan kasus. Intisari Sains Medis 10(2): 442-447. D0I: 10.15562/ism.v10i2.408

\section{PENDAHULUAN}

Bagi sebagian besar laki-laki, ukuran penis merupakan hal yang penting dan bahkan menjadi sumber kekhawatiran. Selama lebih dari satu abad, pola pemikiran "Semakin besar, semakin baik" tidaklah berubah. ${ }^{1}$ Adanya stigma pada ukuran penis yang kecil dimana dianggap sebagai hal yang memalukan, menyebabkan peningkatan permintaan untuk memperbesar ukuran penis. Padahal sebagian besar laki-laki yang menginginkan operasi untuk meningkatkan ukuran penis memiliki ukuran dan fungsi penis yang normal. Masalah kepercayaan diri ataupun keinginan untuk 
memberikan kepuasan yang lebih untuk pasangan menjadi tekanan serta beban pikiran, dan menjadi alasan oleh sebagian laki-laki untuk melakukan hal-hal yang dapat meningkatkan ukuran penis.

Beberapa etnis dan budaya memiliki beragam cara yang dipercaya dapat meningkatkan ukuran penis. Misalnya saja dengan menambahkan pemberat pada penis, menambahkan implan, dan bahkan hingga menghandalkan gigitan dari ular beracun. ${ }^{1,2}$ Berdasarkan sejarah, implan pada penis dengan menggunakan berbagai benda seperti batu mulia, emas batangan, ball bearing, atau cincin, sudah diterapkan sejak zaman dahulu oleh lakilaki di beberapa Negara Asia Tenggara, seperti Indonesia, Filipina, Thailand, dan Malaysia. ${ }^{2}$ Namun belum ada kesimpulan yang pasti mengenai darimana awal mula praktik ini. Beberapa penulis berpendapat praktik tersebut dibawa dari luar oleh pedagang dari Cina yang berkunjung ke Asia Tenggara dan ada juga yang berpendapat hal tersebut berasal dari inovasi penduduk pribumi. ${ }^{1,2}$

Selain implan, praktik augmentasi penis dengan minyak mineral, contohnya paraffin, sudah diketahui secara luas oleh masyarakat, terutama di Indonesia. Namun prosedur ini dinilai sangat tidak layak karena dapat menyebabkan kerusakan yang berat pada jaringan penis dan organ seki$\operatorname{tar}^{2,3}$ Di ilmu kedokteran, Robert Gersuni adalah orang pertama yang menggunakan minyak mineral sebagai injeksi pada tahun 1899. Injeksi dilakukan pada kantong skrotum yang bertujuan sebagai pengganti testis pasca operasi orchidectomy bilateral akibat epididymitis tuberculosis., ${ }^{2,4}$

Saat ini paraffin digunakan sebagai salah satu bahan injeksi pada jaringan subkutan penis dengan tujuan untuk meningkatkan ukuran penis. Paraffin atau minyak eksogen tetap dalam kondisi stabil dan semipadat pada suhu ruangan, tetapi mencair saat keadaan hangat. Kurangnya enzim pada tubuh manusia untuk mendegradasi paraffin, menyebabkan munculnya berbagai komplikasi. Sebagian besar komplikasi berupa deformitas yang merupakan akibat dari reaksi granulomatosa. ${ }^{4,5}$ Reaksi

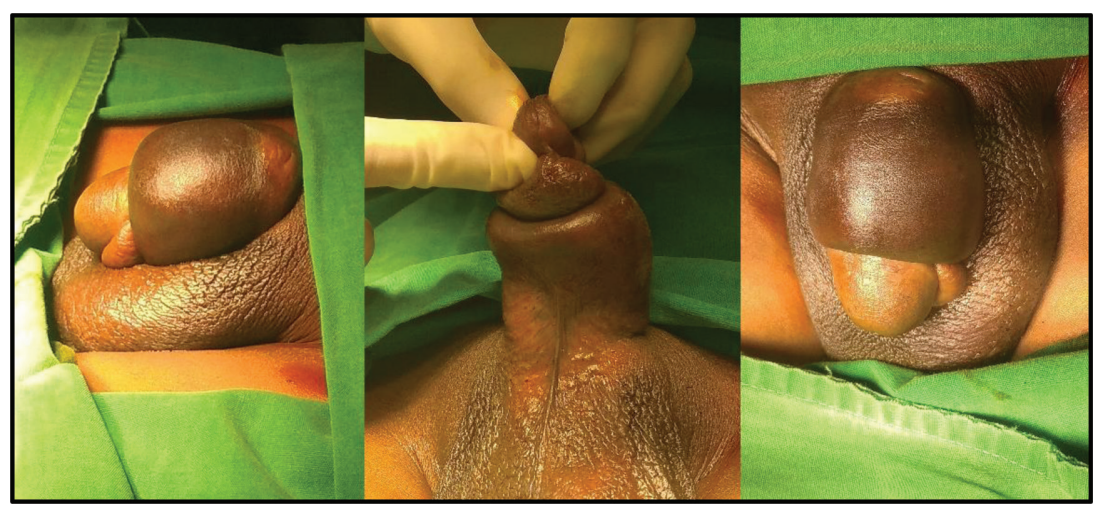

Gambar 1 Foto keadaan awal penis sebelum dilakukan operasi ini menyebabkan sklerosing lipogranuloma atau sering disebut sebagai kasus parafinoma penis. Komplikasi yang ditimbulkan mengakibatkan masalah psikologis hingga stress emosional akibat gangguan aestetik serta fungsional yang berakibat pada impotensi, nyeri saat berhubungan seksual, dan bahkan hingga ketidakmampuan dalam melakukan aktivitas seksual. ${ }^{5}$

Tindakan operasi pada kasus parafinoma penis sangatlah menantang untuk dilakukan. Namun, eksisi material asing dengan teknik phalloplasty yang tepat dapat memberikan hasil yang memuaskan. Pada laporan kasus ini penulis menyajikan kasus sklerosing lipogranuloma penis akibat dari injeksi parafin yang kemudian menjalani prosedur operasi dengan menggunakan teknik two step cutaneous plasty dengan scrotal flap pada shaft penis. ${ }^{6,7}$ Laporan kasus ini akan mencoba menguraikan teknik yang dipergunakan dalam mengatasi kasus sklerosing lipogranuloma penis.

\section{LAPORAN KASUS}

Seorang laki-laki berumur 40 tahun, sudah menikah, dan dikaruniai 3 orang anak, datang ke Poliklinik Urologi, Rumah Sakit Daerah Mangusada Badung dengan keluhan nyeri dan pembengkakan pada penis sejak 3 hari yang lalu. Nyeri dirasakan bertambah berat apabila penis dalam keadaan ereksi. Pasien pernah mendapatkan injeksi pada kulit penis berupa minyak kurang lebih sebanyak $20 \mathrm{ml}$ sekitar 1 tahun yang lalu oleh tenaga non-medis. Informasi mengenai injeksi tersebut didapatkan oleh teman pasien. Harapan akan meningkatknya ukuran penis dan keinginan untuk dapat lebih memuaskan pasangan semakin memotivasi pasien untuk melakukan injeksi pada penis. Pada waktu hari dilakukan injeksi, kurang lebih sekitar 20 orang laki-laki rekan kerja pasien juga melakukan hal yang sama. Saat pemeriksaan pasien merasa sangat kecewa dan sedih dengan bentuk dan fungsi dari kelaminnya saat ini.

Pada pemeriksaan tanda vital dan pemeriksaan fisik secara umum dalam batas normal. Pemeriksaan khusus pada organ genitalia didapatkan pembengkakan pada keseluruhan kulit penis disertai nyeri tekan dan indurasi. Glans penis dalam batas normal dan tidak terdapat nyeri (Gambar 1). Pemeriksaan testis, skrotum, suprapubik, dan limfanodi lokal masih dalam batas normal. Hasil pemeriksaan laboratorium rutin pada sampel darah masih dalam batas normal.

Pada kunjungan awal, pasien diberikan terapi oral berupa nonsteroidal anti-inflammatory drug (NSAID) natrium diclofenac tablet $50 \mathrm{mg}$ setiap 12 jam dan antibiotik cefixime tablet $200 \mathrm{mg}$ setiap 12 jam selama 7 hari, yang bertujuan untuk 


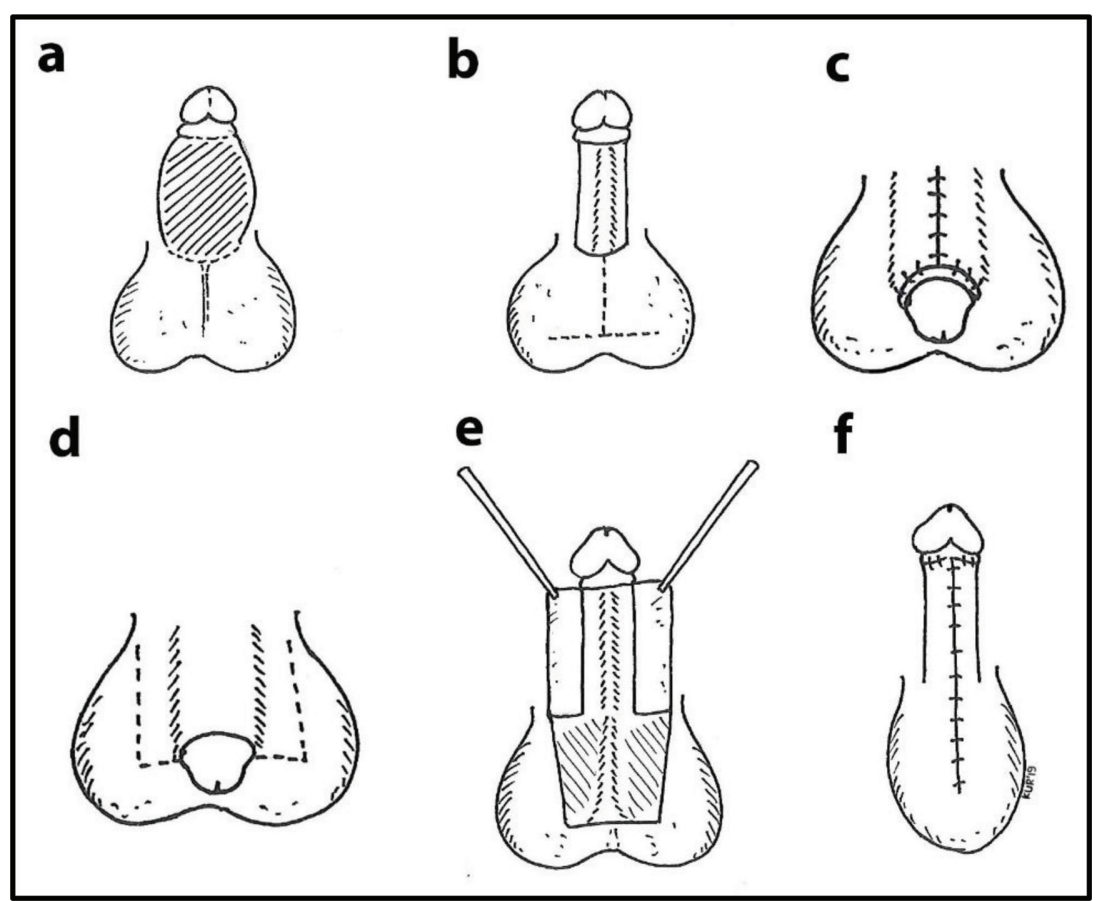

Gambar 2 Teknik operasi two step cutaneous plasty dengan scrotal flap pada shaft penis. $(a, b, c)$ operasi tahap pertama : wide excision serta pembentukan scrotal flap; $(d, e, f)$ operasi tahap kedua : rekonstruksi shaft penis

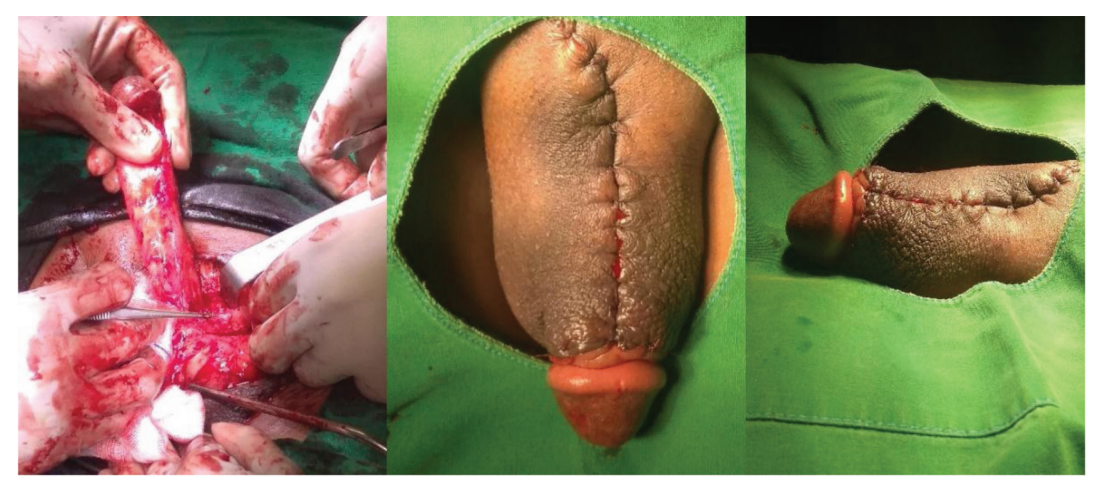

Gambar 3 Foto operasi tahap pertama : wide excision shaft penis \& scrotal flap

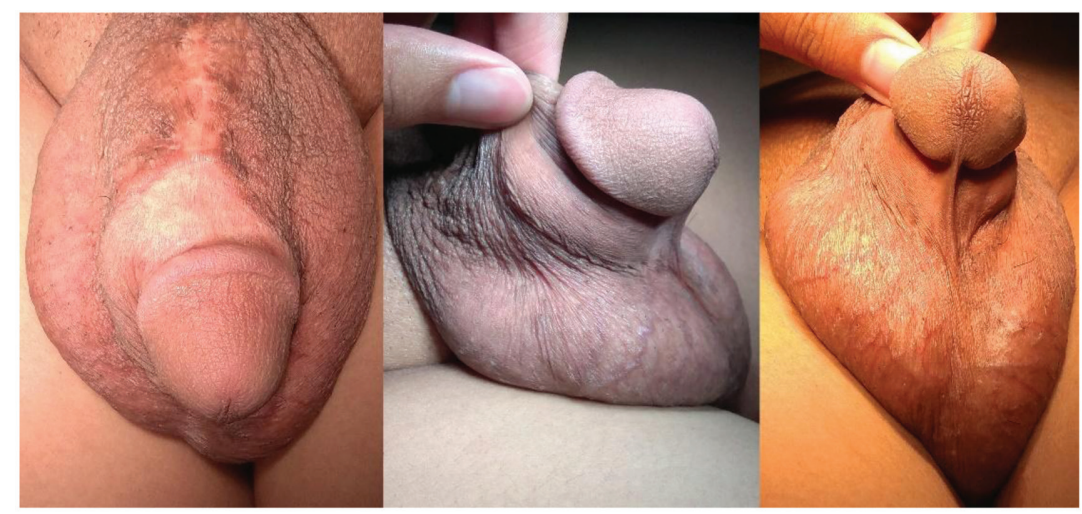

Gambar 4 Hasil operasi tahap pertama setelah 4 bulan mengurangi keluhan nyeri, edema, dan mengatasi infeksi sekunder akibat peradangan. Pasien kemudian mengerti dan setuju untuk tindakan operasi setelah diberikan penjelasan yang lengkap. Tindakan operasi dilakukan dengan teknik two step cutaneous plasty dengan scrotal flap pada shaft penis. Operasi ini dilakukan sebanyak dua tahap (Gambar 2).

Tahap pertama bertujuan untuk menghilangkan jaringan yang mengalami kerusakan akibat injeksi paraffin dengan wide excision pada kulit dan jaringan subkutan. Kemudian dilakukan pembentukan scrotal flap dengan insisi sagittal pada skrotum untuk menutup keseluruhan bagian penis yang telah dieksisi dan dijahit pada bagian dorsal dan koronal (Gambar 3). Bagian kulit dan jaringan subkutan penis yang dieksisi kemudian dikirim ke laboratorium patologi anatomi untuk dilakukan pemeriksaan histopatologi.

Dalam waktu satu minggu pasien disarankan kontrol poliklinis untuk dinilai apakah terdapat hematoma dan infeksi sekunder pasca operasi. Kemudian selama satu bulan diharapkan graft telah menunjukkan adhesi yang baik. Hasil pemeriksaan histologi menunjukkan gambaran yang sesuai dengan reaksi sklerosing lipogranuloma. Operasi tahap kedua dilakukan empat bulan kemudian, saat jaringan dari scrotal flap dinilai cukup untuk rekonstruksi pada shaft penis pasien (Gambar 4).

Rekonstrusi dilakukan dengan insisi lateral pada kedua sisi dan ventral dari penis yang tertanam di skrotum. Penutupan dilakukan dengan penjahitan longitudinal pada sisi ventral penis dan pada skrotum (Gambar 5). Didapatkan hasil yang baik secara aestetik dan fungsional dalam kurun waktu dua bulan pasca operasi.

\section{PEMBAHASAN}

Pada sebagian besar budaya terutama di Asia, memiliki ukuran penis yang besar merupakan sebuah simbol dari kekuatan, kebanggaan, dan maskulinitas bagi seorang pria. ${ }^{1,2}$ Pemikiran ini berbeda dengan wanita, dimana hanya $21 \%$ wanita yang beranggapan bahwa ukuran penis merupakan hal yang penting dan $85 \%$ wanita puas dengan ukuran penis pasangannya. ${ }^{1} \mathrm{Hal}$ ini berarti permasalahan ukuran penis sebagian besar merupakan kekhawatiran dari laki-laki saja. Hingga akhirnya muncul pemikiran untuk meningkatkan ukuran penis, misalnya saja dengan injeksi minyak mineral atau paraffin. Di ilmu kedokteran dermal-fat graft merupakan salah satu prosedur yang dapat meningkatkan ukuran penis. $^{3}$ Namun tingginya biaya yang dibutuhkan, mengakibatkan masyarakat 


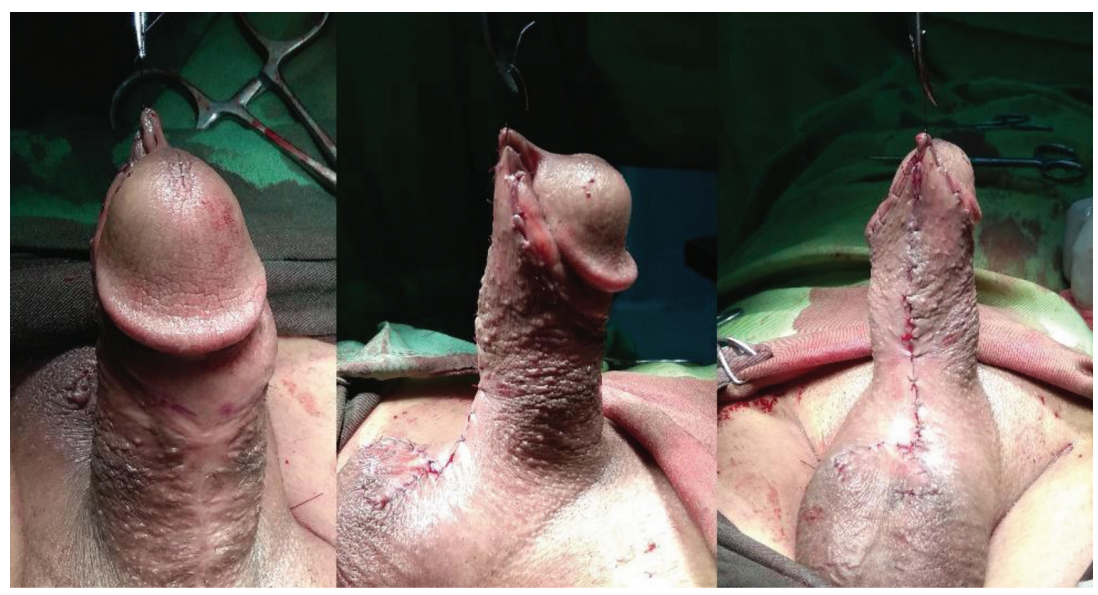

Gambar 5 Hasil tindakan operasi tahap kedua

lebih memilih metode lain yang lebih terjangkau tanpa memikirkan efek samping yang ditimbulkan, misalnya dengan melakukan injeksi minyak mineral atau paraffin. Penggunaan minyak mineral sebagai injeksi pada tubuh sudah tidak disarankan lagi setelah tahun 1917. Hal ini karena didapatkan beberapa laporan mengenai efek samping yang merugikan. ${ }^{2,4,7}$ Walaupun demikian, sampai saat ini masih didapatkan praktik injeksi minyak mineral oleh tenaga non medis ataupun diri sendiri.

Sebagian besar pasien praktik injeksi paraffin berusia 28-32 tahun, dengan usia termuda yang pernah ditemukan yaitu 13 tahun., ${ }^{1,7}$ Alasan terbanyak dari praktik injeksi paraffin yaitu untuk meningkatkan ukuran penis (56\%), mengatasi gangguan fungsi ereksi (32\%), dan adanya rasa kurang percaya diri pada ukuran penis (17\%). ${ }^{1,2}$ Sebagian besar pasien mengaku mendapatkan informasi mengenai praktik injeksi dari teman atau rekan kerja (49\%). ${ }^{1,3}$ Prosedur injeksi biasanya dilakukan oleh tenaga non medis (78\%) baik itu oleh diri sendiri, teman, ataupun orang lain yang direkomendasikan., ${ }^{1,3}$ Setelah dilakukan injeksi pada penis, hanya sekitar $33 \%$ yang puas akan tindakan tersebut dan merasa lebih percaya diri. ${ }^{1}$ Hingga akhirnya muncul reaksi yang merugikan di kemudian hari akibat substansi injeksi tersebut, $90 \%$ pasien merasa tidak puas dengan bentuk dan fungsi penisnya, dan $74 \%$ ingin menghilangkan substansi tersebut. Hanya sekitar $15,6 \%$ yang tidak mengalami efek samping akibat praktik injeksi minyak mineral, hingga waktu yang tidak dapat ditentukan. ${ }^{1}$

Rata-rata pasien mengalami keluhan dalam kurun waktu 36 bulan, dengan variasi waktu antara beberapa hari hingga 30 tahun pasca injeksi. ${ }^{3,7}$ Keluhan lokal yang dapat muncul yaitu nyeri pada penis $(84 \%)$, pembengkakan $(83 \%)$, indurasi $(43 \%)$, produksi sekret purulen (22\%), ulserasi (13\%), dan kemerahan pada penis (9\%). Nyeri pada penis merupakan keluhan yang paling banyak dialami oleh pasien, dapat berupa nyeri intermitten, saat ereksi, ataupun nyeri kronis. Keluhan lain yang lebih berat yaitu berupa nekrosis, Fournier's gangrene, hingga sepsis., ${ }^{2,7}$

Saat pemeriksaan fisik pada penis dapat ditemukan pembengkakan dan eritema. Deformitas pada penis dapat saja ditemukan. Pada kasus akut, lokasi bekas suntikan mungkin dapat terlihat apabila dilakukan pemeriksaan yang teliti. Pemeriksaan palpasi sepanjang shaft penis bermanfaat untuk menemukan area di bawah kulit yang mengalami indurasi. Lesi tersebut dapat dimobilisasi apabila masih dalam batas jaringan kulit, atau terfiksasi apabila terdapat pada bagian yang lebih dalam akibat dari proses fibrosis. ${ }^{89}$ Pada kasus yang disajikan, dari hasil anamnesis adanya riwayat injeksi parafin sejak 1 tahun dan keluhan nyeri dan pembengkakan penis sesuai dengan yang terdapat pada literatur. Ditambah dengan hasil pemeriksaan fisik berupa pembengkakan pada keseluruhan shaft penis, disertai nyeri tekan dan indurasi, semakin mengarahkan diagnosis pada kasus parafinoma penis.

Pemeriksaan penunjang dengan magnetic resonance imaging (MRI) dapat dilakukan untuk menilai lebih dalam apabila terdapat perluasan lesi yang tidak dapat dipalpasi. Selain itu MRI juga dapat digunakan untuk memastikan tidak ada kerusakan pada korpus kavernosus, korpus spongiosum, testis, dan epididimis. Pemeriksaan laboratorium darah lengkap dapat dilakukan untuk menyingkirkan adanya infeksi sistemik sekunder dari infeksi penis yang mengalami komplikasi. ${ }^{8}$

Terapi awal pada parafinoma penis dapat berupa terapi medikamentosa untuk mengatasi proses reaksi inflamasi lokal. Pemberian antibiotik cefalosporin generasi dua atau tiga dan nonsteroidal anti-inflammatory drugs (NSAID) selama 1-2 minggu diharapkan dapat mengurangi reaksi inflamasi lokal. ${ }^{10}$ Pada laporan kasus ini, pasien mendapatkan terapi natrium diclofenac tablet $50 \mathrm{mg}$ setiap 12 jam dan antibiotik cefixime tablet $200 \mathrm{mg}$ setiap 12 jam selama 7 hari. Setelah proses inflamasi dan infeksi lokal telah teratasi, dilanjutkan dengan terapi definitif berupa eksisi luas pada kulit dan jaringan subkutan yang terinfiltrasi oleh parafin disertai dengan tindakan phalloplasty. Operasi ini termasuk prosedur rekonstruksi yang kompleks, membutuhkan waktu yang tidaklah singkat, dan pada beberapa kasus mungkin membutuhkan beberapa tahap operasi apabila timbul komplikasi pasca operasi. ${ }^{5}$ Terdapat beberapa teknik operasi pada kasus parafinoma penis yaitu eksisi parsial dengan penutupan primer, one-sheet spiraling full-thickness skin graft, bilateral scrotal flap, inverted 
ventral $V-Y$ plasty, fasciocutaneous radial forearm free flap, dan two-stage cutaneous plasty dengan scrotal skin.,5,11 Pada laporan kasus ini, penulis menggunakan teknik operasi two-stage cutaneous plasty shaft penis dengan menggunakan scrotal skin yang pertama kali diperkenalkan oleh Cecil pada tahun $1946 .{ }^{12}$ Teknik ini dipilih karena dapat memberikan flap yang cukup luas dan elastis menyerupai kulit penis sehingga memberikan hasil aestetik dan fungsional yang baik, kepuasan pasien yang tinggi, dan dengan komplikasi berupa nekrosis parsial atau hematom yang minimal. ${ }^{4,6,11,13}$ Tindakan operasi dilakukan sebanyak dua tahap. Tahap pertama berupa wide excision pada kulit dan jaringan subkutan yang mengalami kerusakan. Dilanjutkan dengan menutup shaft penis yang kulit dan jaringan subkutannya telah dieksisi dengan scrotal flap. Kulit skrotum dipastikan dalam keadaan sehat dan tidak terdapat infiltrasi substansi injeksi yang luas untuk menghindari terbentuknya kembali kerusakan jaringan akibat substansi paraffin yang tersisa. Operasi tahap kedua dilakukan minimal 3 bulan kemudian, saat jaringan dari scrotal flap dinilai cukup untuk rekonstruksi pada pasien. Pada kasus ini rekonstruksi dilakukan 4 bulan setelah operasi tahap pertama. Didapatkan hasil yang baik secara aestetik dan fungsional dalam kurun waktu 2 bulan pasca operasi.

Pemeriksaan histopatologi dari jaringan yang telah dieksisi penting untuk konfirmasi keberadaan substansi yang telah diinjeksi. Hasil pemeriksaan histopatologi berupa sklerosing lipogranuloma dengan gambaran subtitusi jaringan subkutaneus yang normal oleh rongga kistik yang berisikan substansi minyak. Pada sekeliling rongga ini terdapat jaringan ikat fibrosa padat dan sel inflamasi kronik granulomatosa. ${ }^{5,8}$ Dengan adanya hasil pemeriksaan histopatologi, dapat disingkirkan adanya keganasan berupa karsinoma sel skuamosa (SCC) ${ }^{8}$ Hal ini sangatlah penting karena injeksi minyak mineral memiliki hubungan dengan kejadian karsinoma sel skuamosa. ${ }^{8}$

\section{SIMPULAN}

Parafinoma penis merupakan reaksi inflamasi lipogranulomatosa akibat injeksi substansi paraffin, yang kasusnya masih sering ditemukan hingga saat ini. Efek samping lokal ataupun sistemik dapat timbul pasca injeksi substansi parafin dalam waktu yang bervariasi. Tindakan operasi rekonstruksi merupakan terapi definitif untuk mengatasi permasalahan dari segi aestetik ataupun fungsional. Pada laporan kasus ini, penulis menggunakan teknik operasi two-stage cutaneous plasty shaft penis dengan menggunakan scrotal skin. Teknik operasi ini memberikan hasil aestetik dan fungsional yang baik, kepuasan pasien yang tinggi, dan dengan komplikasi berupa nekrosis parsial atau hematom yang minimal.

\section{UCAPAN TERIMA KASIH}

Ucapan terima kasih penulis berikan kepada pasien dan Bagian Urologi, Rumah Sakit Daerah Mangusada Badung atas kesempatan dan bimbingan yang telah diberikan dalam penulisan laporan kasus ini.

\section{KONFLIK KEPENTINGAN}

Penulis menyatakan tidak terdapat konflik kepentingan (conflict of interest) pada penulisan laporan kasus ini.

\section{PENDANAAN}

Penulis bertanggung jawab terhadap seluruh pembiayaan dalam pembuatan laporan akhir kasus ini.

\section{KONTRIBUSI PENULIS}

Putu Kurnia Darma Pratama bertanggung jawab dalam pembuatan laporan kasus ini. I Putu Gde Sanjaya bertanggung jawab sebagai pembimbing dalam penulisan laporan kasus ini.

\section{DAFTAR PUSTAKA}

1. Sasidaran R, Zain MM, Basiron NH. Low-grade liquid silicone injections as a penile enhancement procedure: Is bigger better?. Urol Ann. 2012; 4: 181-186.

2. Palinrungi MA, Syahrir S, Palinrungi ALR, Krahmadi E, Prihantono P. Characteristics and Treatment of Penile Paraffinoma in Makassar, Indonesia. American Journal of Medical Sciences and Medicine. 2017; 5(3): 53-55.

3. Moon DG, Yoo JW, Bae JH, Han CS, Kim YK, Kim JJ. Sexual function and psychological characteristics of penile paraffinoma. Asian J Androl. 2003; (5): 191-194.

4. Singh M, Singh V, Chang MCL. Penile Paraffinoma. Med J Malaysia. 2015; 70(6): 361-362.

5. Bjurlin MA, Carlsen J, Grevious M, Jordan MD, Taylor A, Divakaruni N, Hollowell CMP. Mineral Oil-induced Sclerosing Lipogranuloma of the Penis. J Clin Aesthet Dermatol. 2010; 3(9):41-44.

6. Celdran JO, Rodriguez CS, Ros MT, Valverde FMG, Egea JPM, Marín MR, et al. Penile paraffinoma after subcutaneous injection of paraffin. Treatment with two step cutaneous plasty of the penile shaft with scrotal skin. Arch. Esp. Urol. 2012; 65(5): 575-578.

7. Svensoy JN, Travers V, Osther PJS. Complications of penile self-injections: investigation of 680 patients with complications following penile self-injections with mineral oil. World J Urol. 2018; 36:135-143. 
8. Ahmed U, Freeman A, Kirkham A, Ralph DJ, Minhas S, Muneer A. Self-injection of foreign materials into the penis. Ann R Coll Surg Engl. 2017; 99:78-82.

9. Picozzi SCM, Carmignani L. Paraffinoma of the penis. Int J Emerg Med. 2010; 3:507-508.

10. Bayraktar N, Basar I. Penile Paraffinoma. Hindawi Publishing Corporation. 2012; 202840.

11. Asanad K, Banapour P, Asanad S, Jabaji R, Chang A. Scrotal flap reconstruction for treatment of erectile dysfunction following penile enhancement with liquid silicone. Urology Case Reports. 2018; 20:75-77.

12. Azmy AF. Cecil-Culp Operation. Pada: Hadidi AT, et al. Hypospadias Surgery. Springer-Verlag Berlin Heidelberg. 2004;283-284.
13. Ungrasmi P, Chayasadom A, Angspatt A. Anatomical and functional outcome after bilateral scrotal flap in penile reconstruction. Asian Biomedicine. 2014; 8(1): 83-86.

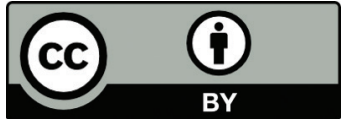

This work is licensed under a Creative Commons Attribution 